\title{
Noteworthy record of the kit fox (Vulpes macrotis) and its relation to physiographic characteristics in Baja California, Mexico
}

\author{
Jonathan G. Escobar-Flores ${ }^{1}$, Sarahi Sandoval ${ }^{2 *}$ and Mariana Delgado-Férnandez ${ }^{1}$ \\ ${ }^{1}$ Centro de Investigaciones Biológicas del Noroeste, S. C. Instituto Politécnico Nacional 195. CP. 23090, La Paz. Baja California Sur, \\ México. Email:jescobar@cibnor.mx (JGEF),mdelgado@pg.cibnor.mx (MDF). \\ ${ }^{2}$ CONACYT-Instituto Politécnico Nacional. CIIDIR. Unidad Durango. Sigma 119, Fraccionamiento 20 de noviembre II, CP. 34220 , \\ Durango. Durango, México. Email: ssandoval@conacyt.mx \\ ${ }^{*}$ Corresponding author
}

The kit fox (Vulpes macrotis) lives in sandy and shallow soils of the Pacific coastal plains and the ecoregion of San Felipe desert. The reports of this species are scarce and in Mexico it is listed as a threatened species. The populations of $V$. macrotis tend to decrease due to the change in the habitat to agricultural land, which has been one of the causes of the disappearance of kit fox populations in Mexico. As part of the project "Characterisation of water bodies in Sierra Santa Isabel, Baja California", 12 camera traps were placed in six watering holes that are visited by wildlife from January to August 2015. Digital terrain elevation models were used to describe three variables: roughness, slope inclination and orientation; these variables are essential for the kit fox to build its burrows, catch its preys and escape from predators. The analyses were also carried out in localities where this carnivore had previously been recorded in Baja California. An analysis of variance was used to determine the existence of similarities or differences between the topographical characteristics of the historical localities and the new record. The first photographic record of the kit fox was obtained in one of the watering holes located within the Valle de los Cirios Flora and Fauna Protection Area. The analyses of variance confirmed that there are no significant differences between roughness $\left(F_{(4,780)}=0.11, P>0.05\right)$, slope inclination $\left(F_{(4,1275)}=0.319, P>0.05\right)$ and orientation $\left(F_{(4,15)}=0.41, P>0.05\right)$, between the historical localities and the site where the new record was obtained. Other carnivores were also recorded in the watering hole, such as the cougar (Puma concolor), bobcat (Lynx rufus), coyote (Canis latrans) and gray fox (Urocyon cinereoargenteus). The presence of the kit fox is likely occasional in the watering hole, because the slopes are greater than 10 degrees and, therefore, these sites are unsuitable for the construction of burrows. However, flat sites with sandy substrates that empty into the Gulf of California occur at a distance of less than $5 \mathrm{~km}$ from the watering hole, which are therefore suitable to be inhabited by the kit fox. The analysis of topographic variables of the historical records coupled with camera traps jointly confirmed that the site with the new record has characteristics that are suitable for the kit fox.

La zorra norteña (Vulpes macrotis) habita en los suelos arenosos y pocos profundos de las planicies costeras del pacifico y de la ecorregión del desierto de San Felipe. Los reportes de esta especie son escasos y en México esta enlistada como una especie amenazada. Las poblaciones de $V$. macrotis tienden a disminuir por la transformación del hábitat a tierras agrícolas, la cual ha sido una de las causantes de la extirpación de poblaciones de zorra norteña en México. Como parte del proyecto "Caracterización de los cuerpos de agua en Sierra Santa Isabel, Baja California", se colocaron 12 cámaras trampa en seis aguajes que son visitados por la fauna silvestre de enero a agosto de 2015 . Mediante modelos digitales de elevación del terreno se describieron tres variables: rugosidad, pendiente y orientación de las laderas, estas variables son esenciales para que la zorra norteña construya sus madrigueras, capture a sus presas y escape de sus depredadores. Los análisis también se realizaron en localidades que previamente se había registrado a este carnívoro en Baja California. Por medio de un análisis de varianza de una vía se determinó si existen similitudes o diferencias entre las características topográficas de las localidades históricas y el nuevo registro. En uno de los aguajes que se ubica dentro del Área de Protección de Flora y Fauna Valle de los Cirios, se obtuvo el primero registro fotográfico de la zorra norteña. Con los análisis de varianza se confirmó que no hay diferencias significativas entre la rugosidad $\left(\mathrm{F}_{(4,780)}=0.11, P>0.05\right)$, pendiente $\left(\mathrm{F}_{(4,1275)}=0.319, P>0.05\right)$ y orientación $\left(\mathrm{F}_{(4,15)}=0.41, P>0.05\right)$, entre las localidades históricas y el sitio donde se obtuvo el nuevo registro. En el aguaje también se registraron otro carnívoros, como el puma (Puma concolor), gato montés (Lynx rufus), coyote (Canis latrans) y zorra gris (Urocyon cinereoargenteus). La presencia de la zorra norteña posiblemente es ocasional en el aguaje, debido a que las pendientes en el lugar son mayores a 10 grados y por lo tanto estos sitios no son idóneos para la construcción de madrigueras. Sin embargo, a una distancia menor a $5 \mathrm{~km}$ del aguaje se encuentran sitios planos con sustratos arenosos que desembocan al Golfo de California, y por lo tanto son idóneos para que la zorra norteña sea residente de esos lugares. Analizando variables topográficas de los registros históricos y mediante fototrampeo se confirmó que el sitio con el nuevo registro tiene características idóneas para la presencia de la zorra norteña.

@ 2017 Asociación Mexicana de Mastozoología, www.mastozoologiamexicana.org

\section{Introduction}

The kit fox is distributed in the northeastern central highlands in Mexico and the Baja California peninsula. The habitat of this species is the desert with xeric scrubland and sandy soils in the Sonoran and Baja California Desert (Álvarez-Castañeda 2000; Alvarez-Castañeda et al. 2008). Based on its conservation status according to NOM-059-2010 of SEMARNAT, this species is listed as threatened.
In Baja California, the records of the desert fox are scarce (Álvarez-Castaneada et al. 2015). Huey (1964) mentions the following localities where they this species has been collected and recorded in the state: Valle de la Trinidad $\left(31.38^{\circ}\right.$ $\left.\mathrm{N},-115.65^{\circ} \mathrm{W}\right)$ as the highest-altitude collection site $(834 \mathrm{~m})$; the other locality is San Felipe $\left(31.09^{\circ} \mathrm{N},-114.97^{\circ} \mathrm{W}\right)$, where Huey collected specimens that are preserved in the San Diego Natural History Museum (SDHM). Another relevant 
locality in the state of Baja California is La Ventana $\left(31.78^{\circ} \mathrm{N}\right.$, $-115.08^{\circ} \mathrm{W}$ ), where a fur was collected and there are records of photographic that can be consulted in the vertebrate collection of Universidad Autónoma de Baja California (UABC-572). All these sites are located to the north part of the state, while for the central and southern regions a single skull has been collected dating back to 1970 in Bahía Los Angeles $\left(28.98^{\circ} \mathrm{N}\right.$, $\left.-113.53^{\circ} \mathrm{W}\right)$; the material is safeguarded in the mammals collection of the California Academy of Science (CAS-AM15692). This collection is the only record within the Valle de los Cirios Flora and Fauna Protection Area (APFFVC), which is the largest in Mexico (2,521,776 hectares), and according to the management program of this protected area, there is potentially suitable habitat for this species (Valle de los Cirios Flora and Fauna Protection Area 2013).

\section{Materials and Methods}

As part of the project "Characterisation of water bodies in Sierra Santa Isabel, Baja California", financed by the JiJi Foundation, 12 Bushnell HD camera traps were placed in six watering holes from January to August 2015. Cameras were programed to operate 24 hours and make three photographs and a 5-second video when movement was detected. The sampling effort was estimated by multiplying the number of cameras by the total number of trap nights.

The vegetation in the flat sampling sites and hills consists of xerophitic shrubland with the following dominant species: Larrea tridentata, Prosopis microphylla, Cercidium microphyllum and Pachycereus discolor. In the riverbanks and watering holes, the dominant species are: Psorothamnus spinosus, Tamarix ramosissima, Lupinus excubitus, Encelia farinosa, Juncus acutus (González-Abraham et al. 2010). The climate is semi-warm, with maximum temperatures of $45{ }^{\circ} \mathrm{C}$ in the summer. The mean annual precipitation in the slopes close to the Gulf of California is less than $50 \mathrm{~mm}$, while in the central and northern parts of the sierra the precipitation ranges between 100 and $150 \mathrm{~mm}$ (Roberts and Ezcurra 2012).

The similarities between habitats where $V$. macrotis has been registered were determined by analyzing three topographic variables: slope inclination, orientation and roughness. These variables are associated with the sites where this species has its burrows, feeds and avoids predators (Warrick and Cypher 1988). These were calculated by means of digital terrain elevation models (MDT) with a 30-meter resolution. These were obtained from the United States Geological Survey (USGS) webpage. The models were generated from synthetic aperture radar images acquired during the SRTM Shuttle Radar Topography Mission mission (NASA).

Digital terrain elevation models were processed using the Quantum GIS program (QGIS Development Team 2016). The terrain analysis functions were used for calculating the terrain slope inclination, orientation and roughness. The calculation corresponds to a radius of $5 \mathrm{~km}$ around each record available for the kit fox. This area covers the minimum home range registered for this species (Zoellick et al. 2002). The slope inclina- tion was measured in degrees, and the orientation was classified into four classes: northeast $\left(0^{\circ}\right.$ to $\left.90^{\circ}\right)$, northwest $\left(91^{\circ}\right.$ to $\left.180^{\circ}\right)$, southwest $\left(181^{\circ}\right.$ to $\left.270^{\circ}\right)$, and southeast $\left(271^{\circ}\right.$ to $\left.360^{\circ}\right)$. The terrain roughness was interpreted as follows: sites with values lower than 30 indicate flat sites with low hills; between 31 to 45, medium sierras with ravines; values greater than 50, high sierras with ravines and steps (Riley et al. 1999; Cyper et al. 2013). The values of the topographic variables obtained for each locality were analyzed using a one-way analysis of variance (ANOVA) in the R Statistics software (R Core Team 2013).

\section{Results}

A sampling effort of 2,880 days/trap yielded 870 videos and 1,369 photographs of birds, mammals and reptiles. Two of them recorded $V$. macrotis in El Junco $\left(29.96^{\circ} \mathrm{N},-114.70^{\circ} \mathrm{W}\right)$ at 00:13 and 00:55 hrs on 26 June 2015 (Figure 1). El Junco is located in Los Vascos basin that empties into the Gulf of California and is characterized by permanent springs all year round. (Figure 2). In addition, records of coyote (Canis latrans), gray fox (Urocyon cinereoargenteus), bobcat (Lynx rufus), and cougar (Puma concolor) were also obtained at El Junco.

The ANOVA for each topographic variables indicate that there are no significant differences between the values of the slope inclination $\left(F_{4,1275}=0.319, P>0.05\right)$, orientation $\left(F_{4,15}=\right.$ $0.41, P>0.05)$, and roughness $\left(F_{4,780}=0.11, P>0.05\right)$ between the historical localities and the new record of the kit fox in Baja California. The average value of the slope in El Junco was $34.24^{\circ}$, with minimum values of $0.35^{\circ}$ and maximum of $70.01^{\circ}$. The values of terrain roughness correspond to flat and low mountain ranges that represented $58.28 \%$ (1.323 pixels) of the total area (Figure 3 ). The lower values of slope and roughness were obtained for Bahía Los Angeles and La Ventana (Table 1). Slope orientation was similar in all locations, with the northwest as the most frequent orientation on average (Table 1).

\section{Discussion}

El Junco is characterized for being an isolated site with virtually no impact by anthropogenic activities. Rocky substrates in streams and slopes are not the type habitat for V. macrotis, although there are some records in similar topographical conditions, as was the case reported in the state of Sonora (VeronaTrejo et al. 2012). It is known that the fox is vulnerable to predation in these sites (Cyper et al. 2013). The presence of the desert fox is likely occasional in the new record, as the slopes in the
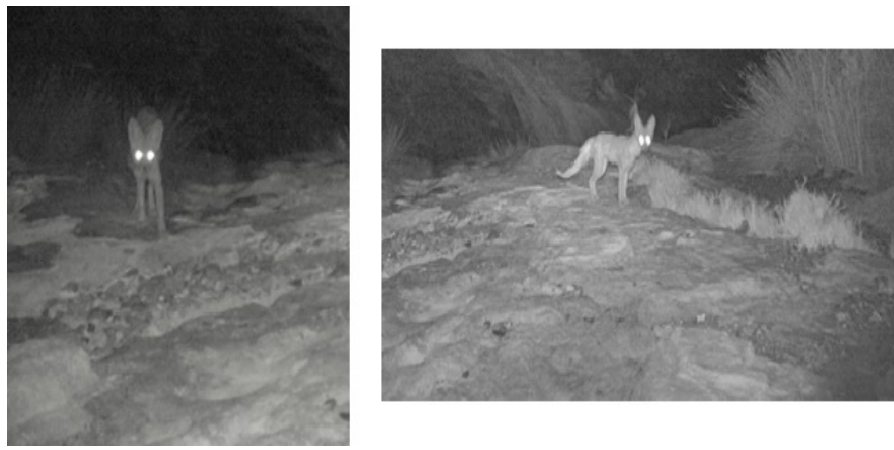

Figure 1. First photographic records of Vulpes macrotis in APFFVC 


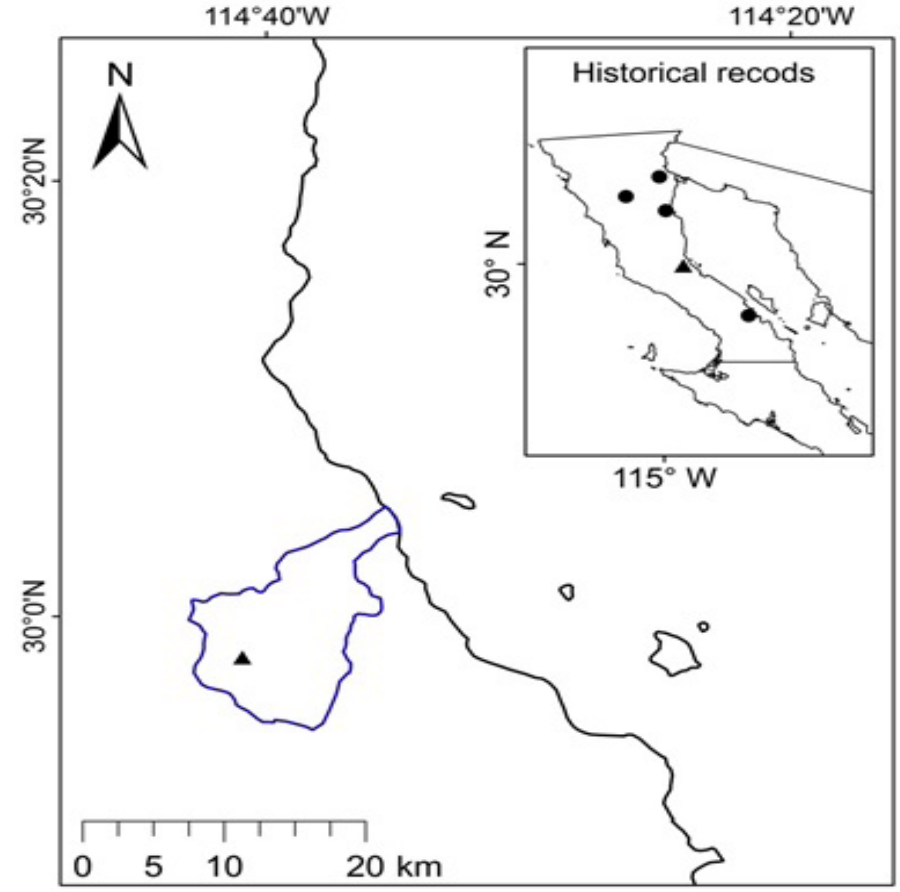

Figure 2. Record locality of Vulpex macrotis, in El Junco (black triangle), and historical record localities (black circles) in Baja California. The blue color represents Los Vascos basin.

area are greater than 10 degrees, and therefore not suitable for the construction of burrows (1998 Cyper and Spencer; List and Macdonald 2003; Harrison 2003; González-Bernal 2008). However, there are plains and sandy substrates less than $5 \mathrm{~km}$ to the east of El Junco, who have topographical features (roughness, slope and orientation) similar to those in the localities of historical records; hence, the presence of a resident population on the slopes that lead to the Gulf of California is likely, where the main preys of the kit fox e. g., kangaroo rat (Dipodomys simulans), field rat (Neotoma sp.) and hare (Lepus californicus; White et al. 1996).

In a single night, the kit fox can travel distances between 10 and $15 \mathrm{~km}$ (Zoellick et al. 2002); therefore, it can travel daily across the whole Los Vascos basin, measuring $17.6 \mathrm{~km}$ long. Despite the absence of watering holes in the Gulf of California slopes, this carnivore is able to meet its water needs through the preys consumed daily, i. e., $175 \mathrm{~g}$ of food, which represent approximately two rat specimens (Neotoma sp.; Golightly and Ohmart 1984; Olivas 2003).

The topography between the record localities of $V$. macrotis is similar, characterized by slopes inclination lower than $20^{\circ}$, roughness indicative of flat terrain, ideal for this species to escape from predators, and with a broad variety in slope orientations, a condition that favors the occupation of burrows (Cyper et al. 2013). A locality that apparently lacks suitable conditions for V. macrotis, is Valle de la Trinidad, which has an altitudinal gradient of 600 to 900 meters; however, riverbanks show slopes lower than $10^{\circ}$ and are located at less than $15 \mathrm{~km}$ from the San Felipe desert. These conditions facilitate the displacement of the kit fox. The most isolated locality from all the historical records is Bahía Los Angeles, with the closest record located in El Vizcaíno Desert, $125 \mathrm{~km}$ to the southwest (Alvarez-Castañeda et al. 2008). In spite of this, Bahia Los Angeles is
Table 1. Results of the topographic variables at each of the localities where Vulpex macrotis has been recorded in Baja California.

\begin{tabular}{lcrlrlr}
\hline & Slope & \multicolumn{3}{c}{ Roughness } & Aspect \\
\hline Locality & Mean & Stdev & Mean & Stdev & Mean & Stdev \\
& & & & & & \\
El Junco & 34.24 & 15.49 & 92.74 & 44.48 & 179.68 & 104.53 \\
Ventana & 13.46 & 12.50 & 22.29 & 25.67 & 117.78 & 106.76 \\
San Felipe & 31.60 & 13.79 & 59.52 & 24.67 & 179.42 & 107.88 \\
V. Trinidad & 18.56 & 12.09 & 45.90 & 37.61 & 178.14 & 96.01 \\
B. Los Angeles & 12.40 & 8.14 & 25.73 & 19.86 & 174.30 & 106.25 \\
\hline
\end{tabular}

topographically similar in its streams and valleys that flow into the Gulf of California with La Venta, a locality that has the highest number of records of $V$. macrotis in Baja California. Despite no previous record of the kit fox existed in Sierra Santa Isabel, the analysis of topographic variables yielded similar characteristics to those of the localities of the historical records, and the presence of this species was confirmed through camera traps.

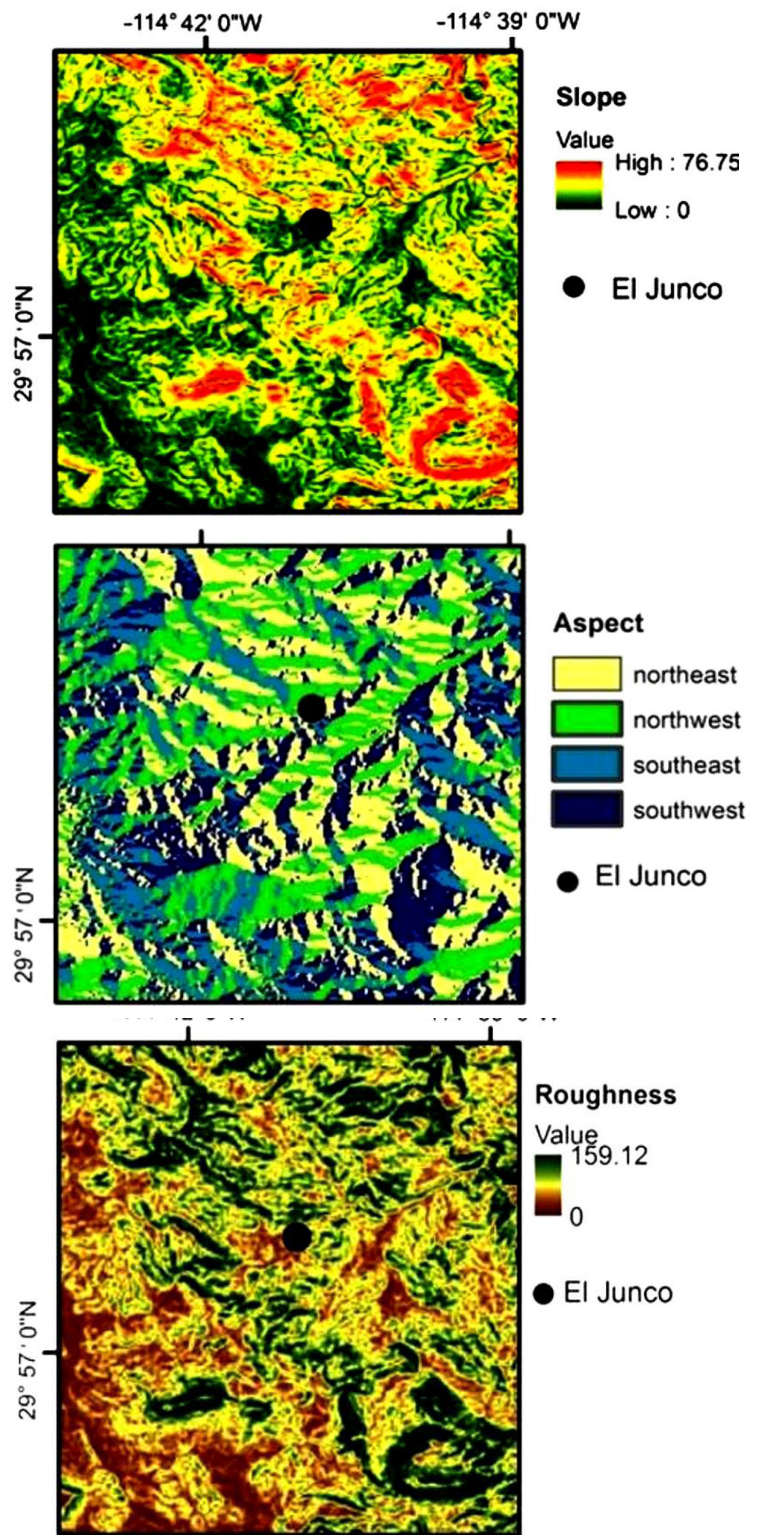

Figure 3. Digital terrain models that describe the topographical variables in El Junco, where Vulpes macrotis was recorded in APFFVC. 
It is recommended to monitor the population of the $V$. macrotis at the mouth of the Los Vascos basin, as well as in streams and hills in Bahía Los Angeles. To determine the existence of resident populations who may be at risk by anthropogenic activities (roads and mining), which are currently on the rise in the region.

\section{Acknowledgments}

To the National Council of Science and Technology (CONACYT) for grant \#205965. To JiJi Foundation for its support in the purchase of equipment. To the company No-MetÁlicos of Hidalgo, S. A. de C. V. To the guides E. Espinoza, R. Masia and A. Guerrero, for their assistance in the field. To the owners of El Volcán UMA (Units for wildlife management, conservation and use). To the Secretariat of the Environment, Natural Resources and Fisheries (SEMARNAT) for the collection license 07585/13. To O. E. Delgado and M. T. Fernandez for their logistical support. To S. Ticul Alvarez for his valuable comments and suggestions to this manuscript. María Elena Sánchez-Salazar translated the manuscript into English with support of THERYA through a CONACYT grant

\section{Literature cited}

Álvarez-Castañeda, S. T. 2000. Familia Canidae. Pp. 689-705, in Mamíferos del Noroeste Mexicano II. (Álvarez-Castañeda, S. T., and J. L. Patton, eds.). Centro de Investigaciones Biológicas del Noroeste, S. C. La Paz, México.

Álvarez-Castañeda, S. T., Rios, E., Cortés-Calva, P., González-Ruiz, N., and C. G. SuÁrez-Gracida. 2008. Mamíferos de las Reservas de El Valle de los Cirios y El Vizcaíno. Centro de Investigaciones Biológicas del Noroeste, S. C., Comisión Nacional para el Conocimiento y Uso de la Biodiversidad. La Paz, México.

Álvarez-Castañeda, S. T., Alvarez T., and N. Gonzaléz-Ruiz. 2015. Guía para la identificación de los mamíferos de México en campo y laboratorio. Centro de Investigaciones Biológicas del Noroeste, S. C., Asociación Mexicana de Mastozoología A. C. Guadalajara, México.

Cyper, B. L., And K. A. Spencer. 1998. Competitive interactions between coyotes and San Joaquin kit fox. Journal of Mammalogy 79:204-14.

Cypher, B. L., S. E., Phillips, and P. A. Kelly. 2013. Quantity and distribution of suitable habitat for endangered San Joaquin kit foxes: conservation implications. Canid Biology and Conservation 16:25-31.

GolightLy, R. T., AND R. D. OHMART. 1984. Water economy of two desert Canids: Coyote and Kit Fox. Journal of Mammalogy 65:51-58.

González-Abraham, C., Garcillán, P. P., and E. Ezcurra. 2010. Ecorregiones de la península de Baja California: Una síntesis. Boletín de la Sociedad Botánica de México 87:69-82.

GonzÁlez-Bernal, A. 2008. Distribución de la zorra del desierto (Vulpes macrotis) en relación a sus presas y a su principal depredador, el coyote (Canis latrans). Tesis doctoral. Instituto de Ecología, A. C. Xalapa, México.

Harkison R., And J. Whitaker-Hoagland. 2003. A literature Review of Swift Fox Habitat and den-Site Selection. Pp. 79-89, in The swift fox: ecology and conservation in a changing world. (Sovada, M. A., and L. Carbyn, eds.). Canadian Plains Research Center. Regina, Canada.
Huey, L. M. 1964. The mammals of Baja California, México. Transactions of the San Diego. Society of Natural History 13:85-168.

LIST, R., AND D. MACDONALD. 2003. Home range and habitat use of the kit fox (Vulpes macrotis) in prairie dog (Cyanomys ludovicianus) complex. Journal of Zoology 259:1-5.

Olivas, M. M. 2003. Peso de neonatos de rata magueyera (Neotoma albigula leucodon), en cautiverio, del nacimiento a los 40 días de edad, en México. Agrociencia 37:231-235.

Plan de Manejo Valle de los Cirios. 2013. Programa de Manejo del Área de Protección Flora y Fauna Valle de los Cirios. Comisión Nacional de Áreas Naturales Protegidas. Guerrero Negro, México.

QGIS DeVelopment Team. 2016. QGIS Geographic Information System. Open source Geospatial Foundation. URL: http// qgis.osgeo.org

R CORE TEAM. 2013. R: A language and environment for statistical computing. R Foundation for Statistical Computing. Vienna, Austria.URL: http://www.R-project.org/.

Roberts, N., and E. Ezcurra. 2012. Desert Climate. Pp. 1-23, in Baja California Plant Field Guide (Rebman, J. P., and N. C. Roberts, eds.). San Diego Natural History Museum. San Diego, U. S. A.

Riley, S. J., S. D. Degloria, and R. Elliot. 1999. A terrain ruggedness index that quantifies topographic heterogeneity. Intermountain Journal of Sciences 5:23-27.

Verona-Trejo, M. I., Bautista, R., and M. Martínez-Coronel. 2012. Registro de la zorra norteña (Vulpes macrotis) para el sur de Sonora. Therya 3:101-104.

WARRICK, G. D., AND B. L. CYPER. 1998. Factors affecting the spatial distribution of a kit foxes. Journal of Wildlife Management 62:707-717.

White, P. J., Vanderbilt-White, C. A., and K. Ralls. 1996. Function and numerical responses of kit foxes to a short-ter, decline in mammalian prey. Journal of Mammalogy 77:370-376.

Zoellick, B. W., Harris, C. E., Kelly, B. T., O’Farell, T. P., Kato, T. T., AND M. E. Koopman. 2002. Movements and home range of San Joaquin kit foxes relative to oil-field development. Western North American Naturalist 62:151-159.

Associated editor: Sergio Ticul Álvarez-Castañeda Submitted: June 22, 2016; Reviewed: October 4, 2016;

Accepted: January 7, 2016; Published on line: January 20, 2017 